\title{
Akibat Hukum Pembatalan Perkawinan dalam Perspektif Hukum Perlindungan Anak dan Perempuan di Pengadilan Agama Sumatera Selatan*
}

\author{
Sri Turatmiyah, M. Syaifuddin dan Arfianna Novera \\ Fakultas Hukum Universitas Sriwijaya \\ Jl. Palembang - Prabumulih KM. 32 Kabupaten OI Sumatera Selatan \\ efka_turatmiyah@yahoo.com
}

\begin{abstract}
This study discusses the factors causing the cancellation of the marriage in the Religious Court of Palembang, Lubuklinggau, Muaraenim and its legal consequences for the child and the wife. The study was conducted normatively supported by empirical evidences. The study concluded that first, in Decision No. 0587 / Pdt.G / 2013 / PA.Plg and 796 / Pdt.G / 2010 / PA.Llg contributing factor of marriage cancellation is unpermitted polygamy and unauthorized guardian. Secondly, the legal consequences for the child according to Article 28 of Marriage Law is that the child remain legitimate and for his wife in good faith, the marriage still posseses a legal effect which is valid for a husband and wife. If the marriage took place without the goodwill of the husband and wife, as a result of the marriage law it did not exist. The judges' decision is retroactive to when the marriage took place.
\end{abstract}

Keywords: Cancellation of Marriage, as a result of the law, legal protection.

\begin{abstract}
Abstrak
Penelitian ini membahas faktor penyebab pembatalan perkawinan di PA Palembang, Lubuklinggau, Muaraenim serta akibat hukumnya bagi anak dan istri. Penelitian dilakukan secara normatif yang didukung dengan empiris. Penelitian ini menyimpulkan pertama, dalam Putusan No. 0587/Pdt.G/2013/PA.Plg dan No.796/Pdt.G/2010/PA.Llg faktor penyebabnya karena poligami tanpa izin dan wali yang tidak sah. Kedua, akibat hukum bagi anak Pasal 28 UUP tetap anak sah dan bagi istri dengan itikad baik, perkawinan tetap mempunyai akibat hukum yang sah bagi suami dan istri. Apabila perkawinan dilangsungkan tanpa adanya itikad baik dari suami dan istri, akibat hukum perkawinan tersebut sama sekali tidak ada. Keputusan hakim berlaku surut sampai pada saat perkawinan dilangsungkan.
\end{abstract}

Kata Kunci: Pembatalan perkawinan, akibat hukum, perlindungan hukum.

* Artikel ini merupakan ringkasan hasil Penelitian Fundamental tahun 2014 yang dibiayai dari Anggaran DIPA Universitas Sriwijaya Nomor: 023.04.2.415112/2014 tanggal 05 Desember 2013 Daftar Isian Pelaksanaan Anggaran Universitas Sriwijaya sesuai dengan Surat Perjanjian Pelaksanaan Pekerjaan Penelitian Fundamental Universitas Sriwijaya Nomor: 122/UN9.3.1/LT/2014, 20 Maret 2014. 


\section{Pendahuluan}

Lahirnya Undang-Undang No. 1 Tahun 1974 tentang Perkawinan khususnya Pasal 2, menggeser pengertian keabsahan perkawinan dalam masyarakat Islam dari pengertian sebelumnya, yaitu perkawinan itu apabila dilakukan telah memenuhi ketentuan rukun dan syarat agama Islam, maka menjadi sah dan diakui dalam kehidupan bermasyarakat dan bernegara. ${ }^{1}$ Jadi perkawinan merupakan "perikatan keagamaan" karena akibat hukumnya adalah mengikat pria dan wanita dalam suatu ikatan lahir dan batin sebagai suami istri dengan tujuan suci dan mulia yang didasarkan atas Ketuhanan Yang Maha Esa. ${ }^{2}$ Ketentuan Pasal 2 ayat (1) dan (2) UU No. 1 Tahun 1974, jelas bahwa perkawinan harus dilakukan menurut aturan agama agar perkawinan itu sah, dan harus dicatat, agar perkawinan diakui keberadaanya dan mempunyai kekuatan hukum. ${ }^{3}$ Hal tersebut ditegaskan dalam KHI Pasal 5 ayat (1) bahwa: "agar terjamin ketertiban perkawinan bagi masyarakat Islam setiap perkawinan harus dicatat. Selanjutnya Pasal 6 ayat (1) KHI bahwa; "untuk memenuhi ketentuan dalam Pasal 5, setiap perkawinan harus dilangsungkan di hadapan dan di bawah pengawasan pegawai pencatat nikah dan "perkawinan yang dilakukan di luar pengawasan pegawai pencatat nikah tidak mempunyai kekuatan hukum" ${ }^{4}$

Suatu perkawinan dapat putus atau berakhir karena beberapa hal, yaitu karena talak yang dijatuhkan suami terhadap istrinya, atau perceraian atau sebabsebab lain salah satunya karena fasakh atau pembatalan perkawinan yang dijatuhkan oleh pengadilan. Dalam hal terjadinya pembatalan perkawinan (fasakh) yang diatur dalam UU No. 1 Tahun 1974 dan KHI, dimaksudkan untuk penyempurnaan ketentuan perkawinan juga untuk mengantisipasi kemungkinankemungkinan yang timbul di kemudian hari berupa hak waris, perwalian, hak

\footnotetext{
${ }^{1}$ Ambo Asse, "Pernikahan di Bawah Tangan (Nikah Sirri) Termasuk Perbuatan Melawan Hukum”, Jurnal Varia Peradilan, Tahun XXIX No. 344 Juli 2014, Ikatan Hakim Indonesia, Jakarta, hlm. 139. 2.

2 Muhammad Syaifuddin, Sri Turatmiyah, Annalisa Y, Hukum Perceraian, Sinar Grafika, Jakarta, 2013, hlm.

${ }^{3}$ Isnawati Rais, "Kedudukan Hukum Perempuan Dalam Undang-Undang Perkawinan (UUP) “The Legal Position of Women In Marriage Regulation”, Jurnal Legislasi Indonesia, Vol. 7 No. 2 Edisi Agustus 2010, Ditjen Peraturan Perundang-Undangan Kementerian Hukum dan HAM RI, Jakarta, hlm. 190.

${ }^{4}$ Muhammad Rizki, "Konsep "Rekayasan Sosial” kaitannya dengan Hukum Perkawinan (Suatu Telaah Terhadap Nikah Sirri)", Jurnal Varia Peradilan, Tahun XXV No. 297 Agustus 2010, Ikatan Hakim Indonesia, Jakarta, hlm. 48.
} 
nafkah seperti kedudukan anak (nasab) dan hak istri. Sebagaimana dalam Pasal 22 UU No. 1 Tahun 1974 bahwa: "Perkawinan dapat dibatalkan, apabila para pihak tidak memenuhi syarat-syarat untuk melangsungkan perkawinan". Permohonan pembatalan perkawinan diajukan ke Pengadilan dalam daerah hukum tempat perkawinan dilangsungkan, atau di tempat tinggal suami istri.

Di Pengadilan Agama dalam wilayah hukum Sumatera Selatan, misalnya di Palembang, dalam waktu 2 (dua) tahun terakhir telah menjatuhkan putusan pembatalan perkawinan antara, Putusan N0. 1322/Pdt.G/2012/PA.Plg tanggal 17 Desember 2013, No. 0587/Pdt.G/2013/Pa.Plg tanggal 12 Februari 2014, serta putusan No. 796/Pdt.G/2010/PA.LLg tanggal 10 Desember 2010. Di wilayah hukum PA Muaraenim, pernah ada permohonan pembatalan perkawinan tahun 2010, tetapi tidak sampai diputuskan oleh Pengadilan, karena alasan para pihak tidak pernah hadir dalam sidang Pengadilan. Dari beberapa putusan tersebut tentunya dilatarbelakangi oleh berbagai faktor yang berlainan. Sebagai faktor penyebab pembatalan perkawinan, karena perkawinan yang bersangkutan tidak memenuhi syarat-syarat yang ditentukan dalam Undang-Undang. Akibat adanya pembatalan perkawinan sudah pasti menimbulkan konsekuensi. Seperti halnya perceraian, pembatalan perkawinan juga membawa konsekuensi yang tidak jauh berbeda dengan masalah perceraian, dalam kaitannya dengan perkawinan antara dua orang hal tersebut juga turut mempengaruhi status dari anak yang dilahirkan.

\section{Rumusan Masalah}

Berdasarkan uraian dalam latar belakang tersebut, diambil permasalahan tentang, pertama, faktor-faktor apakah yang menyebabkan terjadinya pembatalan perkawinan di wilayah hukum Pengadilan Agama Palembang, Lubuklinggau dan Muaraenim? Kedua, bagaimana akibat hukum dari pembatalan perkawinan yang memberikan perlindungan terhadap anak dan istri dari perkawinan yang dibatalkan? 


\section{Tujuan Penelitian}

Adapun tujuan penelitian ini, pertama, untuk menganalisis faktor penyebab pembatalan perkawinan. Kedua, mengetahui akibat hukumnya bagi anak dan istri dari pembatalan perkawinan tersebut.

\section{Metode Penelitian}

Penelitian ini merupakan penelitian hukum (yuridis normatif) yang dilengkapi dengan yuridis empiris. Penelitian yuridis normatif dilakukan melalui studi kepustakaan yaitu mengkaji, menganalisis tentang pembatalan perkawinan baik menurut UU No. 1 Tahun 1974, PP No. 9 Tahun 1975 maupun Kompilasi Hukum Islam (KHI). Penelitian yuridis empiris dilakukan melalui wawancara terstruktur dengan nara sumber di Pengadilan Agama Palembang, Lubuklinggau dan Muaraenim dalam Putusan No. 0587/Pdt.G/2013/Pa.Plg tanggal 12 Februari 2014 serta Putusan No. 796/Pdt.G/2010/PA.LLg tanggal 10 Desember 2010.

Adapun sumber data yang digunakan adalah data sekunder berupa bahan hukum primer, sekunder dan tersier. Alasan diambilnya putusan 2010 karena dalam 5 (lima tahun) terakhir dalam wilayah hukum Pengadilan Agama Lubuklinggau dan Muaraenim tidak ada permohonan pembatalan perkawinan yang masuk ke pengadilan.

Latar belakang mengambil lokasi penelitian ini karena ketiga wilayah hukum Pengadilan Agama tersebut berada dalam lingkungan kota besar dan terpadat penduduknya di Sumatera Selatan, dengan pertimbangan kesadaran hukum masyarakatnya sudah baik dan meningkat tentu akan berdampak pada semakin meningkatnya perkara-perkara hukum yang diajukan ke pengadilan.

Metode pendekatan ini dilengkapi dengan: Pertama, pendekatan perundang-undangan (Statute Approach), yaitu pendekatan ini digunakan untuk memperoleh deskripsi analisis peraturan hukum yang mengatur tentang pembatalan perkawinan. Kedua, pendekatan kasus (case approach), pendekatan ini digunakan untuk menelaah kasus-kasus mengenai pembatalan perkawinan di Pengadilan Agama Palembang, Kabupaten Muaraenim dan Kota Lubklinggau yang telah diputus untuk dijadikan referensi bagi suatu ilmu hukum. Data yang 
terkumpul diolah dan dianalis secara deskriptif kualitatif untuk mendapatkan kesimpulan.

\section{Hasil Penelitian dan Pembahasan}

\section{Faktor Penyebab Terjadinya Pembatalan Perkawinan di Wilayah Hukum Sumatera Selatan}

Adanya pembatalan perkawinan yang dilakukan oleh istri pertama sebagai istri sah terkait perkawinan suaminya yang dilakukan tanpa izin, sudah pasti menimbulkan akibat hukum pada para pihak. Hal tersebut akan berkaitan dengan bentuk perlindungan hukum bagi para pihak dalam pembatalan perkawinan. Landasan teoritis yang berkaitan dengan pembatalan perkawinan adalah teori perlindungan hukum.

Perlindungan hukum sebagai jaminan hak dan kewajiban manusia dalam rangka memenuhi kepentingan sendiri maupun dalam hubungan dengan manusia lain. Menurut Kamus Besar Bahasa Indonesia, bahwa perlindungan hukum adalah perbuatan (hal tahu peraturan) untuk menjaga dan melindungi subjek hukum berdasarkan peraturan perundangan-undangan yang berlaku. Berkaitan dengan hal tersebut, subjek hukum yang harus mendapat perlindungan hukum adalah anak-anak dan istri sebagai akibat dari pembatalan perkawinan. Kegiatan perlindungan bukanlah suatu monopoli seseorang atau badan/organisasi swasta atau pemerintah dan bukan tanpa saling pengertian satu sama lain. Melainkan kepentingan bersama, dengan tujuan melindungi yang diarahkan kepada kemampuan dan mengemban sense of achiavement sehingga bermanfaat dalam pembangunan semesta nasional.

Sebagaimana ketentuan Pasal 22 UU No. 1 Tahun 1974, pembatalan perkawinan terjadi karena para pihak tidak memenuhi syarat-syarat untuk melangsungkan perkawinan. Alasan pembatalan perkawinan menurut Pasal 27 ayat (1) UU No. 1 Tahun 1974, jika perkawinan dilakukan di bawah ancaman yang melanggar hukum. Kemudian ayat (2) nya, jika salah satu pihak memalsukan identitas dirinya misalnya memalsukan usia, status, dan agama. 
Dalam Pasal 24 UU No. 1 Tahun 1974 menyatakan, bahwa pembatalan perkawinan dapat dilakukan jika salah satu pihak atau kedua belah pihak dan atas dasar masih adanya perkawinan. Selain itu, Pasal $71 \mathrm{KHI}$ menentukan bahwa: "perkawinan dapat dibatalkan jika perkawinan dilangsungkan tanpa wali atau dilaksanakan oleh wali yang tidak berhak. Wali nikah dalam Pasal $20 \mathrm{KHI}$ adalah wali nasab dan wali hakim. Ditegaskan dalam Pasal 23 KHI bahwa wali hakim baru bertindak sebagai wali nikah apabila wali nasab tidak ada atau tidak mungkin menghadirkannya atau tidak diketahui tempat tinggalnya atau ghaib atau adlal atau enggan.

Permohonan pembatalan perkawinan diajukan ke Pengadilan dalam daerah hukum tempat perkawinan dilaksanakan atau di tempat tinggal suami istri. Hasil penelitian ini menunjukkan bahwa pembatalan perkawinan di wilayah hukum Pengadilan Agama Palembang, dengan Putusan No. 0587/Pdt.G/2013/PA.Plg pada 12 Februari 2014, dengan faktor ijin poligami yang tidak sesuai dengan ketentuan peraturan perundang-undangan. Poligami dilakukan tanpa ada persetujuan dari pihak isteri yang sah, dan tanpa ada ijin dari Pengadilan Agama, serta adanya data/identitas yang tidak sesuai dengan keadaan sebenarnya. Kemudian Putusan No. 1322/Pdt.G/2012/PA.Plg. yang telah diputus pada 17 Desember 2013, karena perkawinannya telah menggunakan data yang palsu mengenai "wali nikah". Perkawinan dilakukan dengan "wali nikah yang tidak berhak".

Pembatalan perkawinan yang terjadi di wilayah hukum Kota Lubuklinggau dengan Putusan No.796/Pdt.G/2010/PA.LLg., 10 Desember 2010, faktor penyebabnya karena "wali nikah yang tidak berhak". Karena perkawinan yang kedua dilakukan tanpa menggunakan prosedur yang ditentukan dan banyak ditemukan data identitas yang tidak sesuai dengan data sebenarnya. Hal tersebut sesuai dengan ketentuan Pasal 71 KHI sub " $\mathrm{e}$ " bahwa: perkawinan dilangsungkan tanpa wali atau dilaksanakan oleh wali yang tidak berhak. Wali nikah dalam Islam merupakan rukun yang harus dipenuhi bagi calon mempelai perempuan sebagaimana diatur dalam Pasal 20 KHI. Wali nikah tersebut terdiri dari wali nasab dan wali hakim yaitu seorang laki-laki yang memenuhi syarat hukum Islam. Dari beberapa aturan tersebut berkaitan dengan hukum 
perkawinan sebagai suatu sistem yang terdiri dari berbagai variable dan universal yang mengatur tentang perkawinan secara substansi antara lain: UU No. 1 Tahun 1974, PP No. 9 Tahun 1975, Kompilasi Hukum Islam (KHI yang berlaku dengan Inpres No. 1 Tahun 1991.

Dari hasil wawancara dengan Bakhtiar Kepala Humas dan Hakim pada Pengadilan Agama Muaraenim, 14 Agustus 2014 diperoleh keterangan bahwa dalam kurun waktu 5 (lima) tahun terakhir tidak ada permohonan pembatalan perkawinan yang masuk ke pengadilan. Disampaikan pada 2010 pernah ada, hal itupun tidak selesai tidak sampai diputuskan hakim karena para pihak tidak pernah hadir di persidangan. Maka hakim memutuskan perkara tersebut tidak perlu dilanjutkan.

Secara umum, pembatalan perkawinan dilakukan karena syarat-syarat perkawinan tidak dipenuhi sesuai dengan ketentuan perundang-undangan yang berlaku. Perkawinan sebagai suatu perjanjian yang menimbulkan akibat hukum bagi para pihak. Dalam ajaran Islam, perkawinan itu tidaklah hanya sebagai suatu perjanjian biasa, melainkan merupakan suatu perjanjian suci, dimana kedua belah pihak dihubungkan menjadi pasangan suami istri atau saling meminta menjadi pasangan hidupnya dengan mempergunakan nama Allah. ${ }^{5}$

Dari beberapa putusan pembatalan tersebut di atas, hal ini menjadi jelas bahwa faktor penyebab terjadinya pembatalan perkawinan di wilayah hukum Pengadilan Agama Palembang, Muaraenim dan Lubuklinggau antara lain, pertama, adanya pengelabuan hukum karena perkawinan yang kedua dari pihak Termohon dilakukan dengan menggunakan data atau identitas yang tidak sesuai dengan keadaan sebenarnya. Kedua, perkawinan tersebut menggunakan data palsu khususnya "wali nikah". Ditegaskan di sini bahwa, wali dalam perkawinan tersebut bukan "wali yang berhak", maka berakibat perkawinan tersebut menjadi "cacat hukum" dan batal demi hukum. Dari uraian tersebut pada intinya adalah ada penyebab terjadinya pembatalan perkawinan yaitu: Pertama, pelanggaran prosudural perkawinan. Contohnya, tidak terpenuhinya syarat-syarat wali nikah, tidak dihadiri para saksi dan alasan prosudural lainnya. Kedua, pelanggaran

${ }^{5}$ Abdul Rohim, "Kedudukan Hukum Perjanjian Perkawinan Sebagai Alasan Perceraian", Masalah-Masalah Hukum, Jilid 41 No. 1 Edisi Januari 2012, F.H.Universitas Diponegoro, Semarang, hlm. 62. 
terhadapa materi perkawinan. Contohnya, perkawinan yang dilangsungkan dibawah ancaman, terjadi salah sangka mengenai calon suami dan istri.

\section{Akibat Hukum dari Pembatalan Perkawinan terhadap Anak dan Istri dari Perkawinan yang Dibatalkan}

\section{Akibat Hukum terhadap Anak}

Pembatalan dari kata batal, menganggap tidak sah, atau tidak pernah ada. Pembatalan perkawinan berarti menganggap perkawinan yang telah dilakukan sebagai peristiwa yang tidak sah atau dianggap tidak pernah ada. Perlindungan hukum selalu berkaitan dengan adanya hak dan kewajiban. Akibat pembatalan perkawinan sebagaimana ketentuan Pasal 28 ayat (2a) UU No. 1 Tahun 1974 bahwa: "keputusan pembatalan perkawinan tidak berlaku surut terhadap anakanak yang dilahirkan dari perkawinan tersebut". Hal tersebut ditegaskan dalam Pasal 75 dan 76 KHI. Anak-anak tetap menjadi anak yang "sah" sehingga pembatalan perkawinan tidak akan memutuskan hubungan hukum antara anak dengan orang tuanya. Kedua orang tua wajib memelihara dan mendidik anakanak mereka dengan sebaik-baiknya meskipun perkawinan mereka telah dibatalkan oleh Pengadilan. Hal tersebut terjadi karena perkawinan merupakan persoalan yang harus tunduk pada ketentuan perundang-undangan. Secara keperdataan perkawinan akan memberikan jaminan perlindungan hukum kepada pihak-pihak yang terkait dengan perkawinan, baik suami, isteri, anak maupun pihak ketiga. Perkawinan sebagai suatu perbuatan hukum maka mempunyai akibat hukum dan akibat hukum itu dikehendaki oleh yang bertindak. 6

Keberadaan anak dalam hukum keluarga merupakan sesuatu yang sangat berarti. Anak memiliki arti yang berbeda-beda bagi setiap orang. Anak merupakan penyambung keturunan, sebagai investasi masa depan, dan harapan untuk menjadi sandaran di kala usia lanjut. Anak merupakan pemegang keistimewaan orang tua, waktu orang tua masih hidup, anak sebagai penenang 104.

${ }^{6}$ CST. Kansil dan Christine ST. Kansil, Pengantar Ilmu Hukum Indonesia, Rineka Cipta, Jakarta, 2011, hlm. 
dan sewaktu orang tua meninggal, anak adalah lambang penerus dan lambang keadilan. Anak mewarisi tanda-tanda kesamaan dengan orang tuanya, termasuk ciri khas, baik maupun buruk, tinggi maupun rendah. Anak adalah belahan jiwa dan potongan daging orang tuanya. ${ }^{7}$ Berkaitan dengan pensyari'atan perkawinan dengan tujuan untuk mempunyai keturunan yang baik, memelihara nasab, menghindarkan diri dari penyakit dan menciptakan keluarga yang sakinah. Pertimbangan hakim dalam memutuskan perkara pembatalan perkawinan, hakim dalam prakteknya tidak hanya sebagai mulut (corong) undang-undang atau peraturan tertulis. Dalam kenyataannya undang-undang tidak pernah lengkap atau kadang-kadang tidak jelas yang dapat menghambat hakim memutus perkara. Dari hal itu maka berkembanglah ajaran seperti penafsiran, konstruksi, atau penghalusan hukum. Bahkan hakim dilarang menolak mengadili dengan alasan tidak ada aturan hukum atau hukum yang tidak jelas. Hakim wajib menemukan hukum, sehingga putusannya akan dinilai dengan objektif bagi masyarakat umumnya dan khususnya bagi pencari keadilan. Bahkan putusan hakim dikatakan sebagai "Mahkota" maka pada saat itu pikiran terkonsentrasi pada kemuliaan tingginya pertimbangan hukum putusan hakim. ${ }^{8}$

Mengingat ketentuan Pasal 42 UU No. 1 Tahun 1974 bahwa: "anak yang sah adalah anak yang dilahirkan dalam atau sebagai akibat perkawinan yang sah". Oleh sebab itu sah atau tidaknya suatu perkawinan berkaitan erat dengan akibat hukum dari suatu perkawinan, diantaranya kedudukan serta perlindungan hukum bagi anak dan istri serta harta benda dalam perkawinan. Akibat hukum perkawinan berkaitan erat dengan keabsahan anak serta hak dan kewajiban para pihak, maka syarat dan rukun perkawinan baik menurut UU No. 1 Tahun 1974 maupun KHI harus dipenuhi oleh pihak-pihak yang akan melangsungkan perkawinan. Oleh sebab itu hukum, baik yang dibuat oleh badan tertentu dalam suatu negara atau yang tumbuh dan berkembang dalam masyarakat, akan secara

7 Wijayanto Setiawan, "Hak Waris Anak Luar Kawin yang Lahir dari Perkawinan Campuran Menurut KUHPerdata dan UU No. 1 Tahun 1974 tentang Perkawinan", Jurnal Hukum dan Pembangunan Tahun ke-42 No. 2, Edisi April 2012, Fakultas Hukum Universitas Indonesia, Jakarta, hlm. 202.

${ }^{8}$ H.M. Fauzan, “Aequitas Dalam Pertimbangan Hukum Putusan Hakim”, Varia Peradilan Tahun XXIX No. 345, Agustus 2014, Ikatan Hakim Indonesia, Jakarta, hlm. 34. 
efektif berfungsi mewujudkan ketertiban dan keadilan manakala perilaku anggota dalam masyarakat sesuai dengan hukum itu. ${ }^{9}$

Jika dalam hal peraturan perundang-undangan belum jelas, belum lengkap atau tidak dapat membantu hakim dalam menyelesaikan perkara, maka hakim harus bertindak atas inisiatifnya sendiri untuk menyelesaikan perkara yang bersangkutan. ${ }^{10}$ Oleh sebab itu, pembatalan perkawinan tidak berakibat surut terhadap status anak. Anak tetap sebagai anak sah dan tidak akan memutuskan hubungan hukum antara anak dengan orang tuanya. Perkawinan yang telah dibatalkan tetap menimbulkan akibat hukum baik terhadap suami istri, maupun terhadap anak-anak mereka, jika perkawinan tersebut dilangsungkan dengan itikad baik. Berdasarkan pengertian tersebut pada intinya menyatakan bahwa putusan pembatalan perkawinan tidak berlaku surut terhadap anak yang dilahirkan dari perkawinan tersebut. Jadi walaupun perkawinan kedua orangtuanya oleh pengadilan telah diputuskan dibatalkan, akan tetapi putusan pengadilan tidak mempengaruhi kedudukan anak yang dilahirkan dalam perkawinan tersebut dan mereka tetap dianggap anak sah yang dilahirkan dari suatu perkawinan yang sah.

Ditegaskan oleh H. Muchsin Hakim Agung Mahkamah Agung, bahwa anak merupakan amanah dan anugerah Tuhan Yang Maha Esa yang dalam dirinya melekat harkat dan martabat sebagai manusia yanag seutuhnya. Anak dengan segala keterbatasannya tidak berdaya, sehingga orang dewasa yang menjadi penentu pada cerah atau suramnya nasib dan masa depan anak. Anak harus mendapatkan perlindungan hukum karena: pertama, anak adalah generasi penerus dan masa depan bangsa, kedua, anak adalah kelompok masyarakat yang secara kodrati lemah, negara sebagai pemegang otoritas untuk menjaga dan melindungi setiap warganya tidak terkecuali anak. ${ }^{11}$ Pembatalan perkawinan harus mendapat perhatian dari berbagai pihak yang terkait, karena berdampak terhadap anak dan istri. Hak-hak keperdataan anak jangan sampai terabaikan,

9 Anna Triningsih, "Pengadilan Sebagai Lembaga Penegakan Hukum (Perspektif Civil law dan Common Law)", Jurnal Konstitusi, Vol. 12 Nomor 1, Maret 2015, Kepaniteraan dan Sekretariatan Jenderal Mahkamah Konstitusi RI, Jakarta, hlm. 142.

${ }^{10}$ Ibid., hlm, 94.

${ }^{11}$ H. Muchsin, "Perlindungan Anak Dalam Perspektif Hukum Positif (Tinjauan Hukum Adminstrasi Negara, Hukum Perdata, dan Hukum Pidana)", Varia Peradilan Tahun XXVI, No. 308, Edisi Juli 2011, Ikatan Hakim Indonesia, Jakarta, hlm. 5. 
sehingga diperlukan upaya-upaya untuk memberikan jaminan bagi terpeliharanya hak-hak keperdataan anak. Lembaga peradilan dalam hal ini mempunyai peranan penting untuk menjamin hak-hak keperdataan anak lewat putusan-putusannya. Karena anak yang lahir dari perkawinan tersebut harus dilindungi dan diperhatikan kesejahteraan dan kepentingannya, karena anaklah yang paling merasakan akibatnya. ${ }^{12}$

Sebagaimana ditegaskan dalam Pasal 1 ayat (2) UU No. 23 Tahun 2002 tentang Perlindungan Anak bahwa: "Perlindungan anak adalah segala kegiatan untuk menjamin dan melindungi anak dan hak-haknya agar dapat hidup, tumbuh, berkembang dan berpartisipasi secara optimal sesuai dengan harkat dan martabat kemanusiaan, serta mendapat perlindungan dari kekerasan dan diskriminasi". Dari pengertian tersebut, ada hal penting yaitu adanya jaminan dan perlindungan terhadap hak-hak keperdataan anak serta adanya jaminan dan perlindungan terhadap anak dari berbagai tindak kekerasan dan diskriminasi.

Anak yang dilahirkan dari orang tua yang perkawinannya telah dibatalkan oleh pengadilan, tetap mendapatkan perlindungan hukum sebagaimana halnya anak yang perkawinan orang tuanya masih ada. Konvensi PBB tentang Hak-hak Anak 1989 yang telah diratifikasi melalui Keputusan Presiden No. 36 Tahun 1990 mengatur bahwa hak anak merupakan bagian integral dari hak asasi manusia dan Konvensi Hak Anak merupakan bagian integral dari instrumen tentang hak asasi manusia (HAM). Hak anak tersebut antara lain: non diskriminasi (Pasal 2 Konvensi Hak Anak), kepentingan terbaik bagi anak (Pasal 3), hak hidup, kelangsungan hidup dan perkembangan (Pasal 60) dan penghargaan terhadap pendapat anak (Pasal 12).

Hak-hak anak dalam Konvensi Hak Anak tersebut telah diadopsi dalam beberapa undang-undang seperti UU No. 39 Tahun 1999 tentang HAM, UU No. 23 Tahun 2002 tentang Perlindungan Anak. Selain itu diatur juga dalam Pasal 28 B ayat (2) UUD 1945 yang berbunyi: "setiap anak berhak atas kelangsungan hidup, tumbuh daan berkembang serta berhak atas perlindungan dari kekerasan dan diskriminasi. Anak yang dilahirkan dari perkawinan yang dibatalkan tetap

12 H. Muchsin, "Perlindungan Hukum Terhadap Anak Pasca Perceraian Orang Tua", Varia Peradilan, Tahun XXVI No. 310, Edisi Desember 2010, Ikatan Hakim Indonesia, Jakarta, hlm. 7. 
mendapatkan hak-hak keperdataan, sebagaimana dalam Pasal 45 ayat (1) dan ayat (2) UU No. 1 Tahun 1974, bahwa kedua orang tua wajib memelihara dan mendidik anak-anak mereka sebaik-baiknya. Kewajiban orang tua tersebut berlaku sampai anak itu kawin atau dapat berdiri sendiri, kewajiban mana berlaku terus meskipun perkawinan antara kedua orang tua putus.

Pada prinsipnya setiap anak berhak untuk dapat hidup, tumbuh, berkembang dan berpartisipasi secara wajar sesuai dengan harkat dan martabat kemanusiaan, serta mendapat perlindungan dari kekerasan dan diskriminasi, hak atas nama sebagai identitas dan status kewarganegaraan, hak beribadah, berpikir dan berekspresi. Hak mendapat pelayanan kesehatan dan jaminan sosial, hak memperoleh pendidikan dan pengajaran, hak memperoleh akta kelahiran, hak waris. Negara sebagai pemegang otoritas untuk menjaga dan melindungi setiap warganya tidak terkecuali anak, wajib memberikan perhatian dan perlindungan bagi anak. Perlindungan anak dalam hukum positif ada tiga aspek hukum yang mengatur, yaitu: pertama, hukum administrasi negara hak anak adanya pengakuan sebagai warga negara. Kedua, aspek hukum perdata, sebagamana diatur dalam UU No. 1 Tahun 1974 tentang Perkawinan, UU No. 4 Tahun 1979 tentang Kesejahteraan Anak, UU No. 39 Tahun 1999 tentang HAM, UU No. 23 Tahun 2002 tentang Perlindungan Anak. Ketiga, aspek hukum pidana yaitu perlindungan anak dari tindakan kekerasan dan diskriminasi.

Pembatalan perkawinan harus mendapat perhatian dari berbagai pihak yang terkait, karena berdampak terhadap anak dan istri. Anak yang tentunya banyak menjadi korban akibat perkawinan orang tuanya dibatalkan, sehingga pihak-pihak tersebut perlu memperhatikan nasib anak, sehingga anak tidak menjadi korban. Hak-hak keperdataan anak jangan sampai terabaikan, sehingga diperlukan upaya-upaya untuk memberikan jaminan bagi terpeliharanya hak-hak keperdataan anak. Lembaga peradilan dalam hal ini mempunyai peranan penting untuk menjamin hak-hak keperdataan anak lewat putusan-putusannya. Karena anak yang lahir dari perkawinan tersebut harus dilindungi dan diperhatikan kesejahteraan dan kepentingannya, karena anaklah yang paling merasakan akibatnya. Putusan pembatalan perkawinan bertujuan mengakhiri atau menyelesaikan suatu sengketa ketika dirasakan adanya pelanggaran hak. Putusan 
mendudukan dengan jelas hubungan dan kedudukan hukum antara paihak yang bersengketa. Putusan memberikan kepastian tentang hak maupun hubungan hukum para pihak yang bersengketa. ${ }^{13}$

\section{Akibat Hukum terhadap Istri}

Perlindungan hukum terhadap istri sebagai akibat perkawinan yang dibatalkan, sebagaimana diatur dalam Pasal 28 ayat (2) butir (b) UU No. 1 Tahun 1974 menentukan bahwa: keputusan pembatalan perkawinan tidak berlaku surut terhadap suami atau isteri yang bertindak dengan itikad baik, kecuali terhadap harta bersama bila pembatalan perkawinan didasarkan atas adanya perkawinan lain yang lebih dahulu. Apabila perkawinan didasarkan pada itikad baik dari suami dan istri, maka perkawinan tersebut tetap mempunyai akibat hukum yang sah bagi suami dan istri serta terhadap anak-anak mereka. Sehingga putusan hakim mengenai batalnya perkawinan hanya mempunyai akibat hukum setelah pembatalan tersebut. Sedangkan sebelum adanya pembatalan perkawinan tersebut tetap dianggap sebagai perkawinan yang sah. Hanya saja setelah diputuskan pembatalan perkawinan istri tidak mendapat hak nafkah iddah sebagaimana halnya perceraian.

UU No. 1 Tahun 1974 tidak membahas secara rinci mengenai pembatalan perkawinan. Sesuai dengan ketentuan Pasal 66 UU No. 1 Tahun 1974, maka beberapa ketentuan dalam KUHPerdata mengenai pembatalan perkawinan masih berlaku sepanjang tidak bertentangan dengan UU No. 1 Tahun 1974 tersebut. Akibat hukum dari pembatalan perkawinan diatur dalam Pasal 28 UU No. 1 Tahun 1974 dan Pasal 95-98 KUHPerdata yang dibedakan menjadi: pertama, adanya itikad baik dari suami dan istri, kedua, hanya salah satu pihak yang beritikad baik, ketiga, tidak adanya itikad baik dari suami dan istri. Harta kekayaan yang diperoleh selama perkawinan hingga putusan batalnya perkawinan akan dibagi dua apabila para pihak dalam perkawinan tidak membuat perjanjian kawin. Dalam hal salah satu pihak saja yang beritikad baik maka perkawinan tersebut hanya mempunyai akibat-akibat yang sah dan

\footnotetext{
13 Abdil Baril Basith, "Kebatalan dan Pembatalan Perkawinan Serta Akibat Hukumnya (Analisis terhadap Poligami Lebih Dari Empat)", Varia Peradilan Tahun XXX No. 349, Edisi Desember 2014, Ikatan Hakim Indonesia, Jakarta, hlm. 84.
} 
menguntungkan bagi pihak yang beritikad baik dan anak-anak. Perkawinan yang dilangsungkan tanpa adanya itikad baik dari suami dan istri maka akibat hukum perkawinan tersebut sama sekali tidak ada. Keputusan hakim akan berlaku surut sampai pada saat perkawinan dilangsungkan. Pada perkawinan tersebut tidak terdapat persatuan harta perkawinan. Hal ini dipertegas sebagaimana hasil penelitian lapangan dari wawancara pada Agustus 2014 dengan bapak Cik Basir Hakim Pengadilan Agama Kota Lubuklinggau bahwa istri tidak mendapat perlindungan hukum dari perkawinan yang telah dibatalkan oleh pengadilan. Dalam arti istri tidak mendapatkan nafkah iddah. Karena begitu perkawinan dibatalkan, dianggap sudah tidak ada hubungan hukum lagi terhadap istri. Dari uraian tersebut disimpulkan bahwa keputusan pengadilan tidak berlaku surut dalam arti keputusan pengadilan yang membatalkan perkawinan berlaku saat keputusan pengadilan mempunyai kekuatan hukum tetap (sama dengan saat berlakunya putusan perceraian). Dengan demikian walaupun perkawinan itu tidak sah namun karena perkawinan ini dilakukan dengan itikad baik, maka diberi perkecualian dalam hal harta bersama yang diperoleh selama perkawinan berlangsung, yakni setelah perkawinan dibatalkan masing-masing suami dan istri tetap memperoleh harta bersama. Hal yang sama disampaikan oleh Muchlis Ketua Pengadilan Agama Kabupaten Muaraenim, dan Ahyauddin - hakim Pengadilan Agama Palembang melalui wawancara pada Agustus 2014, bahwa akibat hukum terhadap istri dari pembatalan perkawinan dilihat dari ada tidaknya unsur itikad baik dari kedua pihak. Jika ada unsur itikad baik maka istri berhak atas harta bersama, tetapi tidak mendapatkan nafkah iddah. Dalam pengertian istri tidak mendapat hak-hak perdatanya sebagaimana halnya akibat dari perceraian.

\section{Penutup}

Dari uraian tersebut di atas dan berdasarkan hasil analisis beberapa putusan Pengadilan Agama di wilayah hukum Sumatera Selatan dapat disimpulkan bahwa faktor-faktor penyebab terjadinya pembatalan perkawinan antara lain, pertama, kurangnya informasi dan pengetahuan tentang hukum dari 
masyarakat sehingga terjadi perkawinan yang tidak memenuhi syarat-syarat sebagaimana diatur dalam undang-undang. Hal tersebut terbukti adanya perkawinan yang dilakukan dengan memalsu identitas para pihak sehingga terjadi pengelabuan hukum dari perkawinan yang kedua (poligami) dari pihak Termohon. Kedua, perkawinan tersebut menggunakan data palsu khususnya "wali nikah". Ditegaskan di sini bahwa, wali dalam perkawinan tersebut bukan "wali yang berhak" maka berakibat perkawinan tersebut menjadi "cacat hukum" dan batal demi hukum.

Akibat hukum dari pembatalan perkawinan sudah tentu menimbulkan konsekuensi baik terhadap anak-anak dan istri dari perkawinan yang dibatalkan. Hal tersebut berakibat hukum bahwa anak-anak yang dilahirkan dari perkawinan yang dibatalkan tetap sebagai "anak sah" yang mempunyai hak-hak keperdataan karena: pertama, orang tua tetap mempunyai kewajiban memelihara dan mendidik anak-anak mereka dengan sebaik-baiknya. Kedua, kewajiban orang tua tersebut berlaku sampai anak itu kawin atau dapat berdiri sendiri kewajiban mana berlaku terus meskipun perkawinan antara kedua orang tua putus. Begitu juga terhadap istri, pertama, jika ada itikad baik maka istri tetap mendapatkan harta bersama jika tidak ditentukan lain. Kedua, Istri dari perkawinan yang dibatalkan tidak mendapatkan hak nafkah iddah karena sejak dijatuhkan putusan pembatalan dari pengadilan maka perkawinan tersebut" dianggap tidak pernah terjadi". Dari uraian tersebut maka dapat disimpulkan bahwa anak-anak dan istri dari perkawinan yang dibatalkan tetap mendapat perlindungan hukum apabila perkawinan tersebut dilandasi dengan "itikad baik" dari kedua pihak. Hal ini tentunya disebabkan karena akibat hukum dari pembatalan perkawinan tersebut harus memberi perlindungan dan kepastian hukum yang adil bagi para pihak yang tercermin dalam putusan pengadilan yang dijatuhkan oleh seorang hakim. Perkawinan harus memenuhi syarat-syarat sesuai ketentuan peraturan perundang-undangan yang mengatur tentang perkawinan di Indonesia, baik dalam UU No. 1 Tahun 1974 tentang Perkawinan, PP No. 9 Tahun 1975 maupun KHI. Karena hukum sebagai sebuah sistem yang terdiri dari berbagai variable dan universal. Sesuatu disebut sebagai sistem apabila terdiri dari berbagai rangkaian yang mencakup unsur-unsur, bagian-bagian, konsistensi, kelengkapan 
dan konsepsi atau pengertian dasar. Hal ini dilakukan selain untuk tertib administrasi, juga terpenuhi dan terjaminnya hak-hak para pihak khususnya kaum perempuan, hal ini untuk menghindari perilaku laki-laki atau suami yang tidak bertanggung jawab. Selain itu juga penting jika ada yang dirugikan atau dianiaya dapat menuntut haknya. Aturan ini memberikan kedudukan yang lebih baik kepada perempuan dan melindungi mereka jika terjadi penelantaran.

\section{Daftar Pustaka}

Asse, Ambo, Pernikahan Di Bawah Tangan (Nikah Sirri) Termasuk Perbuatan Melawan Hukum, Jurnal Varia Peradilan, Tahun XXIX No. 344 Juli 2014, Ikatan Hakim Indonesia, Jakarta.

Baril Basith, Abdil, Kebatalan dan Pembatalan Perkawinan Serta Akibat Hukumnya (Analisis terhadap Poligami Lebih Dari Empat), Varia Peradilan Tahun XXX No. 349, Edisi Desember 2014, Ikatan Hakim Indonesia, Jakarta.

Fauzan, H.M. Aequitas Dalam Pertimbangan Hukum Putusan Hakim, Varia Peradilan Tahun XXIX No. 345, Agustus 2014, Ikatan Hakim Indonesia, Jakarta.

Kansil, CST, dan Christine ST., Kansil, Pengantar Ilmu Hukum Indonesia, Rineka Cipta, Jakarta, 2011.

Muchsin, H, Perlindungan Hukum Terhadap Anak Pasca Perceraian Orang Tua, Varia Peradilan, Tahun XXVI No. 310, Edisi Desember 2010, Ikatan Hakim Indonesia, Jakarta.

--------, Perlindungan Anak Dalam Perspektif Hukum Positif (Tinjauan Hukum Adminstrasi Negara, Hukum Perdata, dan Hukum Pidana), Varia Peradilan Tahun XXVI, No. 308, Edisi Juli 2011, Ikatan Hakim Indonesia, Jakarta.

Rais, Isnawati, Kedudukan Hukum Perempuan Dalam Undang-Undang Perkawinan (UUP) "The Legal Position of Women In Marriage Regulation", Jurnal Legislasi Indonesia, Vol. 7 No. 2 Edisi Agustus 2010, Ditjen Peraturan Perundang-Undangan Kementerian Hukum dan HAM RI, Jakarta.

Rizki, Muhammad, Konsep "Rekayasan Sosial" kaitannya Dengan Hukum Perkawinan (Suatu Telaah Terhadap Nikah Sirri), Jurnal Varia Peradilan, Tahun XXV No. 297 Agustus 2010, Ikatan Hakim Indonesia, Jakarta.

Rohim, Abdul, Kedudukan Hukum Perjanjian Perkawinan Sebagai Alasan Perceraian, Masalah-Masalah Hukum, Jilid 41 No. 1 Edisi Januari 2012, Universitas Diponegoro, Semarang. 
Setiawan, Wijayanto, Hak Waris Anak Luar Kawin Yang Lahir Dari Perkawinan Campuran Menurut KUHPerdata dan UU No. 1 Tahun 1974 tentang Perkawinan, Jurnal Hukum dan Pembangunan Tahun ke-42 No. 2, Edisi April 2012, Fakultas Hukum Universitas Indonesia, Jakarta.

Syaifuddin, Muhammad, Sri Turatmiyah, Annalisa Y, Hukum Perceraian, Sinar Grafika, Jakarta, 2013.

Triningsih, Anna, "Pengadilan Sebagai Lembaga Penegakan Hukum (Perspektif Civil law dan Common Law)", Jurnal Konstitusi, Vol. 12 Nomor 1, Maret 2015, Kepaniteraan dan Sekretariatan Jenderal Mahkamah Konstitusi RI, Jakarta. 